\title{
Influence of different spectra of visible light on the antioxidant activity of plants
}

\author{
(C) Valery N. Zelenkov, ${ }^{1,2,4}$ Anatoly A. Lapin, ${ }^{3 *^{+}}$ \\ Vyacheslav V. Latushkin, ${ }^{4}$ and Vladimir. V. Karpachev ${ }^{5}$ \\ ${ }^{1}$ All-Russian Scientific Research Institute of Vegetable Growing Vegetables is a Branch of the Federal \\ Research Center for Vegetable Growing - the Branch of FSBSI "Federal Scientific Vegetable Center"500 \\ Vereya Village. Ramenskoe District. Moscow Region, 140153. Russia.E-mail: ivanova_170@mail.ru \\ ${ }^{2}$ All-Russian Scientific Research Institute of Medicinal and Aromatic Plants. \\ Greene St., 7. Moscow, 117216.Russia.E-mail: zelenkov-raen@mail.ru \\ ${ }^{3}$ ANO Development Strategies Institute. St. Red Proletarian, 16, under. 5. \\ Moscow, 125319.Russia.E-mail: slavalat@yandex.ru \\ ${ }^{4}$ Department of Water Bioreservices and Aquaculture. Kazan Energy University. Krasnoselskaya St., 51. \\ Kazan, 420066. Republic of Tatarstan. Russia. Phone: +7 (843) 519-42-67. E-mail: lapinanatol@mail.ru \\ ${ }^{5}$ All-Russian Scientific Research Institute of Rapeseed. Lipetck, 398037. Boevoy Ave., 26. Russia. \\ E-mail:karpachevv@gmail.com
}

Keywords: seeds, sprout, microgreens, antioxidant properties, germination of seeds, viability, light-emitting diodes, monochromatic radiation.

Growing plants under conditions of closed soil using various technologies allowed physiologists to influence their metabolism. The most "environmentally friendly," and not fully studied, are technologies using light of various spectral composition that affects growth, leaf anatomy, secondary plant metabolites and chloroplast ultrastructure. The problem of directed regulation of components of the production process of phytocenoses during artificial irradiation is an urgent task. The authors have previously published data on the effect of ultraviolet radiation on the biochemical properties of plants. As a continuation of these studies, the purpose of the present work was to study the effect of various spectra of visible light on the antioxidant activity of plants. Influence of monochromatic LED irradiation of different wavelength at equal power of radiation on seed germination and change of total antioxidant activity of Abyssinian and sugar beets is studied in the paper. The level of antioxidant activity during sprouting in the light decreased by $17.8-26.7 \%$ compared to dark sprouting, which can serve as an indicator of a decrease in the level of stressful effects. At the same time, with an increase in the level of stress (in the red light version - a decrease in the biomass of 100 sugar beet sprouts by $41.8 \%$ ), there was an increase in the total antioxidant activity by $8.6 \%$, which, according to the literature, may be associated with the activation of plant antioxidant systems as an adaptive reaction to stress. The stimulating effect of irradiation of seeds and sprouts with green light $(520 \mathrm{~nm})$ is shown - increase of biomass of 100 sprouts by $45.8 \%$ of sugar beet compared to the recommended GOST dark germination, in nougat - by $27.8 \%$. Genetic differences in the reaction of germination of seeds of two crops to monochromatic radiation of different wavelength are established and the need to develop differentiated modes of radiation of seeds when growing microzelenium is justified.

\section{References}

[1] T.P. Yakushenkova. Biochemical features of Brassica oleracea var. Sabellica Ocimum basilicum, Petroselinum crispum when grown on various light spectra. Collection of theses of the All-Russian Scientific Conference with international participation, Kazan September 19-21, 2019. Kazan: Publishing House of Kazan University. 2019. 533p. P.495. DOI: 10.26907/978-5-00130-204-9-2019-495

[2] M. Landi, M. Zivcak, O. Sytar, M. Brestic, S.I. Allakhverdiev. Plasticity of photosynthetic processes and the accumulation of secondary metabolites in plants in response to monochromatic light environments: A review. Biochimica et Biophysica Acta (BBA) - Bioenergetics. 2020. Vol.1861. Iss.2. Article 148131.

[3] Li-li Chen, Kai Zhang, Xiao-chen Gong, Hao-ying Wang, Yue-gao Hu. Effects of different LEDs light spectrum on the growth, leaf anatomy, and chloroplast ultrastructure of potato plantlets in vitro and minituber 

production after transplanting in the greenhouse. Journal of Integrative Agriculture. 2020. Vol.19. Iss.1. P.108-119.

[4] A.A. Tikhomirov et.al. Features Choice of Light Sources for Bio-Technical Life Support Systems for Space Applications. Light \& Engineering. 2018. Vol.26. No.6. P.117-121.

[5] G. Pennisi, A. Pistillo, F. Orsini, A. Cellini, L.F.M. Marcelis. Optimal light intensity for sustainable water and energy use in indoor cultivation of lettuce and basil under red and blue LEDs. Scientia Horticulturae. 2020. Vol.27215. Article 109508.

[6] T. Silva, D.S. Batista, E.A. Fortini, de Castro K.M., W.C. Otoni. Blue and red light affects morphogenesis and 20-hydroxyecdisone content of in vitro Pfaffia glomerata accessions. Journal of Photochemistry and Photobiology B: Biology. 2020. Vol.203. Article 111761.

[7] O.S. Dörr, S. Brezina, D. Rauhut, H. Mibus. Plant architecture and phytochemical composition of basil (Ocimum basilicum L.) under the influence of light from microwave plasma and high-pressure sodium lamps. Journal of Photochemistry and Photobiology B: Biology. 2020. Vol.202. Article 111678.

[8] A.A. Shulgina, A.S. Ivanitsky, I.G. Tarakanov. Influence of LED lighting on morphobiochemical indicators of the plant Stevia rebaudiana Bertoni. Collection of theses of the All-Russian Scientific Conference with international participation, Kazan September 19-21, 2019. Kazan: Publishing House of Kazan University. 2019. 533p. P.490. DOI: $10.26907 / 978-5-00130-204-9-2019-490$

[9] Xiaoyan Zhang, Zhonghua Bian, Xingxing Yuan, Xin Chen, Chungui Lu.A review on the effects of lightemitting diode (LED) light on the nutrients of sprouts and microgreens. Trends in Food Science \& Technology. 2020. Vol.99. P.203-216.

[10] L. Cervantes, M.T. Ariza, J.A. Gómez-Mora, L. Miranda, E. Martínez-Ferri. Light exposure affects fruit quality in different strawberry cultivars under field conditions. Scientia Horticulturae. 2019. Vol.25227. P.291-297.

[11] E. Sukhova, V. Sukhov. Connection of the photochemical reflectance index (PRI) with the photosystem II quantum yield and the nonphotochemical quenching can be dependent on variation of photosynthetic parameters among investigated plants: A meta-analysis. Remote Sensing. 2018. Vol. 10. Article 771. DOI: $10.3390 /$ rs 10050771

[12] N. Platonova et all. The composition and content of phenolic compounds in tea, grown in humid subtropics of Russia. Potravinarstvo Slovak Journal of Food Sciences. 2019. Vol.13. P.32-37. DOI: https://doi.org/10.5219/990

[13] E.S. Belocycenko. Resistance of marine red macroalgae Chondrus pinnulatus to photooxidative stress caused by visible and UV radiation. Collection of theses of the All-Russian Scientific Conference with international participation, Kazan September 19-21, 2019. Kazan: Publishing House of Kazan University. 2019. 533p. P.66. DOI: 10.26907/978-5-00130-204-9-2019-66

[14] Yongkang Tang, Ruixin Mao, Shuangsheng Guo. Effects of LED spectra on growth, gas exchange, antioxidant activity and nutritional quality of vegetable species. Life Sciences in Space Research. 2020. Vol.26. P.77-84.

[15] P. Benincasa, G. Tosti, M. Farneselli, S. Maranghi, M. Guiducci. Phenolic content and antioxidant activity of einkorn and emmer sprouts and wheatgrass obtained under different radiation wavelengths. Annals of Agricultural Sciences. 2020. DOI: https://doi.org/10.1016/j.aoas.2020.02.001

[16] Lingzhi Shao, Yuming Fu, Hui Liu, Hong Liu. Changes of the antioxidant capacity in Gynura bicolor DC under different light sources. Scientia Horticulturae. 2015. Vol.1845. P.40-45.

[17] S. Dutta Gupta, A. Karmakar. Machine vision based evaluation of impact of light emitting diodes (LEDs) on shoot regeneration and the effect of spectral quality on phenolic content and antioxidant capacity in Swertia chirata. Journal of Photochemistry and Photobiology B: Biology. 2017. Vol.174. P.162-172.

[18] R.H. Abdullina, O.A. Timofeev, A.A. Mostyakova. Content of soluble phenolic compounds and ascorbic acid in leaves of Urtica dioica L. depending on the location. Collection of theses of the All-Russian Scientific Conference with international participation, Kazan September 19-21, 2019. Kazan: Publishing House of Kazan University. 2019. 533p. P.66. DOI: 10.26907/978-5-00130-204-9-2019-31

[19] V.N. Zelenkov, Maria I. Ivanova, V.V. Latushkin, and A.A. Lapin. Yield and antioxidant activity of microgreens Petroselinumcrispum. Butlerov Communications. 2020. Vol.61. No.3. P.99-104. DOI: 10.37952/ROI-jbc-01/20-61-3-99

[20] V.N. Zelenkov, V.V. Latushkin, A.A. Lapin, and V.M. Kosolapov. Comparison of the sowing, harvesting and antioxidant properties of seeds and seedlings of a giant field moth (Agrostis gigantea Roth) after air drying and thermal dehydration. Butlerov Communications. 2020. Vol.61. No.3. P.120-125. DOI: 10.37952/ROI-jbc-01/20-61-3-120

[21] V.N. Zelenkov, A.A. Lapin. МВИ-001-44538054-07. Total antioxidant activity. Method of measurement on the coolometric analyzer. VNII Vegetable Growing. Verea, Moscow Region. 2013. 19p. (russian) 